\title{
Migrant workers into contract farmers: processes of labour mobilization in colonial and contemporary Mozambique
}

\author{
Helena Pérez Niño
}

\section{Introduction}

During the post-liberalization period, contract farming schemes have become a recurrent feature of agricultural production in sub-Saharan Africa. Contract farming is not a new phenomenon in the continent but it has gained in magnitude and significance in the past decades (Ochieng 2010; Oya 2012; Prowse 2012; Watts 1994). In some countries and sectors, it is now the predominant form of organizing production and commercialization. In its outgrower form it replaces the kind of exchange that would otherwise take place in open markets with an exchange of agricultural commodities that involves an agreement prior to production between producers and traders (or processors). The contract stipulates the conditions of production, such as the volume deliverable, the price, the provision of inputs and technical assistance and the setting of quality standards. Various multilateral institutions, donors, governments and investors have hailed this kind of farming as the way forward for integrating smallholder farmers into global markets and for overcoming the crises of agricultural financing and marketing (FAO 2012; Will 2013).

Mozambique is one of the African countries - along with Kenya and Senegal in which contract farming is most widely employed, having been introduced into the country in the post-war, liberalization years. It filled a void left by the disappearance of collective farms, marketing boards and other institutions that had organized production and exchange and sourced seed and inputs in the socialist period. It was recently estimated that some 400,000 households in Mozambique - approximately 12 per cent of the rural population - produce under contract (IFAD 2003; World Bank 2005). Contract farming accounts for a sizeable share of the value and volume of agricultural exports; it is one of the most dynamic sources of agricultural income and employment as well as the main channel for the provision of modern inputs for small, household-based farming (INE 2011; FAO 2012). It is particularly prevalent in the production of

\footnotetext{
Helena Pérez Niño is a Postdoctoral Fellow at PLAAS, the Institute for Poverty, Land and Agrarian Studies at the University of the Western Cape in South Africa, where she conducts research on agrarian political economy in Southern Africa. Her work on contract farming and tobacco agriculture focuses on the production relations within households and between farmers and workers in agrarian frontiers. Prior to joining PLAAS, Helena was a teaching fellow on agrarian development, post-conflict transitions and the political economy of development at SOAS, University of London, where she obtained her $\mathrm{PhD}$ with a thesis on post-conflict reconstruction and the tobacco boom on the Malawi-Mozambique borderland. She has published on foreign aid, mining, agriculture and transport sectors in Angola and Mozambique. Email: hpereznino@plaas. org.za
}

(C) International African Institute 2017 
labour-intensive crops - such as tobacco and cotton - that require modern inputs. All of these, in Mozambique, are produced in contract farming schemes. Tobacco is of particular significance for the country's economy, being its most valuable agricultural export with a total value of US\$227 million in $2012 ;^{1}$ its production involves 130,000 farmers clustered in the districts bordering Malawi. ${ }^{2}$

This article explores the rapid expansion of contract farming in the past two decades. It discusses the experiences of contract farmers who produce tobacco under outgrower arrangements with a tobacco leaf trading company. In tobacco production, farmers use their own land, inputs are provided on credit, and family labour is used or a small number of workers hired. ${ }^{3}$ Tobacco contracts demand the coordinated mobilization of household resources and impose enormous effort and risks. Households that fail to produce to requirement stand to lose one of the few sources of income available in a district that is relatively distant from major markets in Mozambique and from alternative forms of employment. In order to comply with the contract, households impose on themselves - and, in some cases, on hired-in workers - disciplinary mechanisms and work conditions that have resulted in the transformation of conjugal, intergenerational and communal relations.

This article argues that the expansion of contract farming in the region was enabled by the previous experiences of today's farmers as labour migrants. Throughout the twentieth century, Angónia - the district featured in this case study - was an epicentre of migrant labour recruitment within Mozambique and for mines and plantations in neighbouring countries. Decades of labour migration resulted in the accelerated commodification of livelihoods, provided experience of commodity production, and subjected people to the rigours of working for wages. In the process, socio-economic differentiation was amplified. Production under contract therefore takes place in a complex field of social relations in which risk and uncertainty are absorbed and deflected by differentiated households. In this form of outsourced production, the risks associated with agricultural production, and the demands linked to the hiring and organization of labour, are shifted onto farming households. This is in marked contrast with such households' past experience as providers of wage workers. Furthermore, by supressing the market mechanism, contract farming can result in an uncoupling of the price of tobacco from the costs of complying with the conditions of the contracts. This gives the tobacco-trading company control over fluctuations in supply and can benefit households that have a greater capacity to cope, or to

\footnotetext{
${ }^{1}$ For comparison, sugar exports amounted to US\$146 million and cotton to US\$38 million (FAOSTAT 2014).

${ }^{2}$ Smaller schemes exist for the production of cotton, fresh vegetables and sugar cane, and pilot schemes have been tried for beans, soya, sesame and poultry in Zambézia and Nampula (Benfica et al. 2005; Woodhouse 2012; Smart and Hanlon 2014). Unlike outgrower schemes in tobacco, the sugar cane estates' contract farming complements the production of the nucleus estate and helps stabilize feed volumes for milling (Jelsma et al. 2010; O'Laughlin and Ibraimo 2013). The marked difference between the model used in tobacco and sugar illustrates the variety of contract farming arrangements, which is challenging for comparative analysis (Oya 2012).

${ }^{3}$ For a discussion of other variants of contract farming and classification typologies, see Baumann (2000), Bijman (2008), Eaton and Shepherd (2001) and UNCTAD (2009).
} 
transmit the pressure to casual and seasonal workers. However, accumulating households that expand their output and reinvest their profits coexist with highly indebted households that struggle to keep afloat as commodity producers. In all cases, the intense engagement in tobacco production transfers the responsibility of coordinating the labour process to members of the household, and reconfigures relations of production and reproduction in the domestic sphere.

The approach in this article places the labour process at the centre of an analysis of contract farming. This differs in many ways from the type of analysis, couched in terms of neoclassical or new institutional economics, that is favoured by scholars and development agencies eager to pronounce contract farming as the way forward in agriculture-based development economies (Bellemare 2010; Eaton and Shepherd 2001; NEPAD 2006; Sautier et al. 2006; UNCTAD 2009; World Bank 2007). While neoclassical approaches focus on measuring the income effect of contract farming on producers and assume that farmers are equal partners in a voluntary bargain (Barrett et al. 2012; Bellemare 2010), a historically grounded approach stresses the need to account for the heterogeneity, socioeconomic differentiation and asymmetric power relations that reveal the contradictory interests within households as well as between farmers, workers and buyers. Similarly, institutionalist accounts of contract farming underscore its function as an arrangement for risk management, which would help overcome the problems associated with missing markets for land, credit and inputs (Bijman 2008; Porter and Phillips-Howard 1997). The experiences of contract farmers discussed here reveal, instead, how risk is shifted from buyers onto farming households. Uncertainty and costs are absorbed and redirected in ways that are mediated by gender and class relations. It is argued, therefore, that awareness of initial conditions, power differentials and the social relations of production has been largely missing from studies of contract farming. To acknowledge these factors is to offer a more complex account of the processes involved.

In densely populated Angónia, migrant workers historically retained access to the land. However, in the post-independence period, labour out-migration first ceased for a period because of wartime displacement and then, after briefly recommencing in the post-war period, became increasingly scarce. In this context, post-conflict contract farming in tobacco became a way of re-absorbing the district's abundant labour by harnessing it for the production of a high-value export agricultural commodity. However, it also set in motion a process in which commodity production was relocated into rural households. This allowed agribusiness firms and traders to retain indirect access to the cheap labour of former migrants while incurring lower production costs than estates and plantations, since - as with labour out-migration - the costs of reproducing the workforce were externalized. The case of the tobacco contract farmers of Angónia addressed in this article expands our understanding of the social division of labour in contract farming in two ways: first, by charting the transformation of household relations around the internalization of commodity production; and second, by analysing the emerging labour relations between households and hired-in workers.

Research was conducted in 2012 and 2013 in Angónia, where the largest number of tobacco contract farmers is concentrated. Fieldwork included archival work, interviews with government officials and company representatives, a survey 
of 102 tobacco-growing households and in-depth interviews with farmers. ${ }^{4}$ The first section of the article reconstructs the dynamics of social reproduction in Angónia during the labour out-migration period. Following that, the tobacco contract farming scheme is introduced and its complex network of labour relations analysed. The article concludes by showing how the current dynamics of contract farming are linked to the population's long historical engagement in labour migration.

\section{Labour out-migration from Angónia}

The district of Angónia was an important source of long-distance migrant workers from the colonial period through to the years immediately following Mozambican independence: most of the male respondents interviewed who were old enough to have been economically active at the time had been labour migrants. Over the past two decades, however, there has been a significant transformation in the district's economic base, and the extreme mobility of workers that characterized Angónia has given way to a localized form of production. Angónia is now the epicentre of tobacco production under contract, and contract farming for tobacco has transformed livelihoods. The separation between wage work done by migrant men and reproductive work done by non-migrant members of the household has all but ended. Instead, household members now negotiate a combination of productive and reproductive work done entirely in their own fields, while some households hire seasonal workers and incorporate tenant farmers. This article traces the transition from livelihoods dependent on migrant work to those dependent on contract farming.

Due to its large population and relatively remote location in central Mozambique, Angónia was progressively transformed into an internal labour reserve of great significance during the colonial period. Already by the mid-seventeenth century, it had been designated as a prazo, one of the densely populated but distant territorial entities that were leased to private concessionaries for military 'pacification' and tax collection. The prazo population was burdened with a combination of poll taxes and forced labour contributions that preceded the extension of the forced labour regime to the rest of the colony in 1899 and its codification under Indigenato ${ }^{5}$ in 1928 (Newitt 1995; O'Laughlin 2000). Patterns of production, consumption and commercialization were reshaped by the extended and periodic absence of migrants who were no longer able to contribute their physical work to household activities, while remittances unleashed new forms of consumption and contributed to the deepening of commodity relations. In central Mozambique, the imposition of mussoco (poll taxes) and chibalo (colonial forced labour) both served to promote labour migration to neighbouring colonies (CEA 1983; Newitt 1995; O'Laughlin 2002; 2013; Newitt and Tornimbeni 2008). Circular migration was institutionalized when Mozambicans, through centralized recruitment and deferred payments, were prevented from settling down in their labour migration destinations. Their mobility was also severely restricted by pass laws.

\footnotetext{
${ }^{4}$ All names have been changed to protect the identity of interviewees; either Portuguese or Chichewa written forms are used.

${ }^{5}$ This was the institutional framework that separated citizens and natives in colonial Mozambique.
} 
Among the oldest respondents interviewed, memories are still alive of men forcibly removed to make them comply with chibalo. As will be shown, the need to raise cash to pay poll taxes, coupled with the forced periodic migration for chibalo, resulted in the monetization of the district and ultimately accelerated the commodification of livelihoods. However, people in Angónia did not experience labour migration as a centrally coordinated system and found ways to subvert the restrictions. For example, clandestine migration was practised extensively in an attempt by migrants to earn cash under more favourable conditions, mainly by strategically evading chibalo and migrating instead to mines and plantations in Rhodesia and the Transvaal. The main labour-recruiting agencies operated from Angónia; the RNLB (Rhodesian Native Labour Bureau) was active in the district throughout the period while the WNLA (Witwatersrand Native Labour Association) had a recruitment office in Angónia until 1913 (BorgesCoelho 1991; Tornimbeni 2000). Budala, one of the oldest respondents in this research, was twice recruited for chibalo and spent three years working in South Africa. The journey to the Transvaal was organized by labour recruiters who paid some cash up front to cover household expenses during his absence and coordinated transport by train and bus. Many years before his own experiences as a migrant worker, Budala's father and other men in his village had taken the same journey but independently, taking some mealie meal with them and, on the way, doing ganyu (casual work) to pay their way south.

With few exceptions, tobacco production under contract is currently the main source of livelihood for the contract farming households interviewed during my research, but most depended on remittances from long-distance labour migration until the early 1980s. Of my respondents, 70 per cent grew up in households in which the fathers were labour migrants to the Sena Sugar Estates on the Zambezi, the mines in Witwatersrand, and the mines and farms in Rhodesia. Furthermore, for the older farmers, this transformation took place during their own lifetime. In roughly one-third of the households interviewed, the main respondent was born in or before 1966 - a year that marks a notional boundary since those born before it would have been economically active before the beginning of the war in Angónia, when people fled to Malawi and labour out-migration from Angónia came to an abrupt end. It was the respondents from these older cohorts - men who were fifteen or older during the 1950s, 1960s and 1970s who directly experienced chibalo, the forced labour regime that was done away with in 1961, and long-distance labour migration. Among all the men interviewed from these cohorts, around 68 per cent had been labour migrants in the years preceding the war. The oldest among them had been to South Africa and Rhodesia, particularly frequent destinations before the 1970s, and many had been taken by bus and train to Chinde, Sena and Marromeu, the sugar estates in the lower Zambezi. ${ }^{6}$ The report of the CEA (Centre for African Studies in Maputo) noted in 1982 that most men interviewed in Angónia had a long history of

\footnotetext{
${ }^{6}$ Among Mozambican respondents, thirty-two were born before 1966 and sixty-eight after 1967. The oldest tobacco farmer interviewed was born in 1940 and the youngest in 1996. Labour outmigration from neighbouring Malawian districts was similarly intense. Englund estimates that all men in Dedza born before 1960 had experienced labour migration to South Africa and Rhodesia (1999).
} 
labour migration and found many who had been migrants for twenty or thirty years (1983: 10). Migration to Malawi consisted of seasonal work on estates and plantations or more permanent jobs in urban areas. In some cases, whole families attempted the move, although during the colonial period only men with passbooks were allowed to relocate. More frequently, husbands would leave their uxorilocal families and return periodically with remittances from migrant work. Women who remained in charge of farming described the prolonged separation as difficult. One practice recorded by the CEA among women farming on their own was the more intense use of riverine gardens (madimba) with year-long access to water and rich loam soils, as these are easier to till than the larger rain-fed fields (minda) that demand more labour (CEA 1983). Labour shortages made households more dependent on help from members of their kin groups and working parties were frequently organized as a way to pool resources during peak labour periods. ${ }^{7}$

After Mozambican independence, when migration to South Africa became more difficult for people from Angónia, a common practice was for men to register as Malawians in order to seek recruitment at the stations across the border. We interviewed several Mozambicans who obtained Malawian passbooks, which allowed them several rounds of employment in the mines of the Witwatersrand. This was the case with Viriato, the father of one of the farmers in the sample, who in the early 1970s had twice been formally recruited for mining work in Rustenburg, South Africa, by obtaining counterfeit Malawian identity papers. Legal, voluntary and clandestine migration could be opportunistically combined as well: another respondent, Samisone, had been taken for chibalo to Machipanda (on the border with Zimbabwe) for work in the railways and saw this as his opportunity to flee to Rhodesia, where he worked for six years.

Remittances and periodic male absence from household agriculture rapidly locked the population of Angónia into commodity relations. Respondents who were labour migrants at the time reported using the remittances to support the agricultural production carried out by their wives. Money sent back by migrants was used to buy agricultural inputs and bicycles and notably to pay for hiring ganyu (casual workers) and to buy cattle. Remittances and experiences abroad also contributed to the transformation of consumption patterns. Older respondents recalled that only those with access to wages could buy the manufactured goods that by mid-century became desirable and necessary, which included agricultural tools, blankets, soap, cooking oil and shoes. In the 1983 report on Angónia, the CEA noted that migrant remittances allowed for higher agricultural productivity and were the main catalyst of social differentiation by allowing some households to gain access to fertilizer, improved seed and ganyu workers (CEA 1983).

There was a slow transition from purely coercive (in the case of chibalo) or evasive (in the case of extraterritorial mining work) incorporation into wage employment to forms of indirect compulsion. Progressively, the monetization of social reproduction, the changed patterns of consumption and the lack of viable and reliable alternative sources of cash in Angónia turned people into willing

\footnotetext{
${ }^{7}$ Work parties were also a frequent occurrence in Malawian districts with intense labour outmigration such as Dedza, the district neighbouring Angónia (Englund 1999).
} 
migrant workers - even if only to save up a fund to establish themselves as farmers. Among the reasons for this shift offered by the respondents, the higher wages accrued by voluntary recruits and the difficulty of escaping chibalo were the most frequently cited. Secondary sources confirm this: by the 1930s, the proportion of workers from Angónia that migrated 'voluntarily' exceeded those drafted through the forced labour system (Vail and White 1980). Through the 1940 s and 1950s, the intensity of labour out-migration was such that out of a total population of 65,681 it was claimed that only a few hundred adult men were present in Prazo Angónia (Borges-Coelho 1993).

An official complained in 1945 that, in Angónia,

One can cross huge areas and only see women and children ... men from Angónia who want to emigrate to the Transvaal stay in Southern Rhodesia for sufficient time to earn some money ... and when they feel ready to undertake the journey to the Rand mines ... they go to the nearest station of the Transvaal railways and buy a train ticket to their destination. (Pires, Relatório de Tete 1945, quoted in Newitt 1995)

These forms of clandestine, voluntary and forced labour migration made Angónia part of the 'Africa of the labour reserves', the concept proposed by Amin (1972) to describe how an African migrant workforce was made available to the mining sectors in Southern Africa and, in this case, also for estates and public works within the Portuguese colony. Periodic labour out-migration was particularly intense in Angónia because it was initially too distant from large markets to sustain commodity production, but so densely populated that labour out-migration became a source of state revenue via taxation and remittance transfers mediated by the state. Political and economic mechanisms such as forced labour and the growing commodification of livelihoods (linked to the need first to pay taxes, then to have cash to buy manufactured goods and agricultural inputs) gradually led to periodic labour mobilization by the Zambezi sugar mills, and by Rhodesia, the Transvaal and Nyasaland, as described by present-day tobacco farmers.

The Marxist literature of the 1970s proposed that the combination of coercion, inducement and systematic externalization of the costs of workers' social reproduction onto their farming households helped ensure the profitability and competitiveness of the sectors that recruited them. Later historiography of labour migration in Southern Africa, however, provided an alternative reading of the social history of labour migration centred on the life experiences, agency and resistance of labour migrants and their families. A vast literature now accounts for a variety of regional trajectories and discusses how migration transformed patterns of socialization, gender and family relations, social patterns of ill health, and identities and political mobilization (Crush 1995; O'Laughlin 2013; Delius 2014; Beinart 2014).

The labour migration system began to unravel as the colonial edifice crumbled. By 1961, forced labour was legally abolished in Portuguese colonies. In the late 1970s, mines and estates turned to less labour-intensive production and extraction methods, and growing urbanization and permanent settlement around mines and plantations allowed the possibility of replacing migrant labour with local casualized labour: labour was no longer in short supply (Crush 1995; O'Laughlin 2013). Furthermore, with the demise of the apartheid regime, movement and settlement restrictions were repealed and the state enforcement of the contract labour system came to an end. The downturn of the migrant labour system had effects on 
livelihoods across the region but was met with different responses according to local conditions (Bush and Cliffe 1984). In parts of southern Mozambique and Lesotho, migrant workers adapted to the reduced demand for labour, but many households continued to depend on labour migration to South Africa, even as conditions changed and fewer people found jobs (Crush and Tshitereke 2001; Ishemu 1995). In northern Malawi, there was a progressive shift to independent and informal migration, which could translate into greater uncertainty but also into more independence (Andersson 2006). In districts of southern Mozambique, income forgone from labour migration was progressively replaced with livelihoods based on petty trading (Farré 2013), while Zimbabwean labour migrants used their wages and South African connections to fund the consolidation of new livelihoods linked to informal trans-border trading (Bolt 2012). Lubkemann describes men in central Mozambique who opted to maintain a meaningful trans-border presence by marrying and setting up 'tuck shops' in Mozambique and Zimbabwe (2009), and Potts studied the lives of migrants who settled down in their former labour destinations (2010). In other areas of Malawi and Mozambique, former trans-border migrants became wage labourers in large-scale domestic agriculture (Christiansen and Kydd 1983; Mkandawire 1985; O'Laughlin 2013). Different land and labour relations led to diverging outcomes. The end of the migrant labour system did not necessarily result in the stabilization of a settled workforce in the migration destinations, nor did it lead to the complete disintegration of circular labour migration. However, labour migration had transformed social reproduction across the region in a host of context-specific and irreversible ways (Potts 2010; O'Laughlin 2013): the outgrower model of contract farming in Angónia is one of these.

People's experience of the demise of labour migration in central Mozambique was complicated by the onset of the Mozambican civil war in the late 1970s. Instigated by Rhodesia and later by RENAMO with its South African backers, the war involved the exploitation of different grievances in diverse regions of the country and escalated in Angónia from around 1984. The hostilities put a sudden end to the possibility of travelling outside the district and soon disrupted the functioning of state farms and family agriculture. RENAMO forces had gathered some support, but their pillaging and forced recruitment became too taxing. Violence intensified: several villages were set on fire and people with links to the administration were targeted. FRELIMO retaliated against villagers suspected of aiding RENAMO. By the time the district capital of Vila Ulongue was attacked in 1987, the government had lost control of the whole district and around 90 per cent of the population had fled to Malawi (Juergensen 1996). ${ }^{8}$

The Mozambican civil war displaced 2 million refugees across international boundaries and 3 to 4 million internally. With over 1.2 million Mozambican refugees, Malawi was the neighbouring country most affected. Without access to land, most of my informants felt despondent; interviews with these former refugees, now returned to their homeland, revealed the hardship of refugee life compounded by

\footnotetext{
${ }^{8}$ The total sample of tobacco producers in the survey consisted of 102 respondents: eighty-one men and twenty women. Of the ninety-six Mozambican respondents, eighty-seven were displaced to Malawi, five migrated elsewhere and four were never displaced during the war. In total, 90 per cent of the respondents were displaced to Malawi.
} 
the boredom of the refugee settlements..$^{9}$ Although many engaged in petty trading and casual labour, the vast majority of male interviewees resorted to migration within Malawi in order to look for jobs in tobacco farming.

The potent pull of the tobacco sector was motivated by the considerable expansion of estate agriculture in central Malawi during the 1980s (Jaffe et al. 1991; Prowse 2013). Medium-sized and large farms were operated by a combination of permanent and seasonal workers as well as labour tenants. It was estimated that around 7 per cent of the total population in Malawi consisted of tobacco tenants, 75 per cent of them in the central region, and that in the district of Kasungu alone tenants and their dependants comprised around 48 per cent of the total population. Nationwide, approximately 1 million labourers and their dependants lived on tobacco estates and it was estimated that around 8 per cent of the workforce in Kasungu, the largest producing district, was composed of Mozambican refugees. ${ }^{10}$

According to respondents' accounts, recruiters from central Malawi would drive trucks to the refugee settlements in the borderland in order to recruit workers. Typically, young single men would be introduced to tobacco agriculture as permanent and seasonal workers, while more experienced farmers and married couples would be engaged as tenants. Young children aged twelve to fifteen were recruited to work alongside older male relatives. Within a sample of 102 farmers, 67 per cent of all men who had been displaced to Malawi and were fifteen or older during the war period had worked for wages. Participation in wage employment was particularly intense among men aged twenty to thirty at the beginning of the war, all of whom became wage workers during the war. Importantly, 81 per cent of the men in wage employment worked on tobacco estates as tenants, permanent and seasonal workers, foremen and child helpers. Women were underrepresented in permanent employment in tobacco, but many, with their partners, were tenants on tobacco farms. A total of 30 per cent of the women interviewed had worked for wages in Malawi, but among those born between 1957 and 1976 - adult women during the war - 50 per cent reported wage labour participation. In many cases men were recruited for tobacco but their families stayed behind in the refugee settlements. Of all the women in the sample, 50 per cent declared relying on income-generating activities such as brewing beer and selling wood and charcoal.

Wage work was the main source of income of the households of the youngest men and women interviewed, who were at the time too young to work themselves but whose parents worked predominantly in tobacco estates (48 per cent of the men and 47 per cent of the women of all ages in the sample of refugees came from households dependent on wage work). Davide, currently a large tobacco farmer in Angónia, had worked as a wage labourer in Kasungu before the war. When the war broke out, he returned to Angónia to pick up his family and

\footnotetext{
${ }^{9}$ Englund also observed how idleness troubled Mozambican refugees in the Dedza district during the early 1990s (1999).

${ }^{10}$ The data stems from a small survey conducted in 1990 and may be underestimated since Chichewa-speaking respondents from Angónia had reasons to conceal their true origin and were able to pass for Malawians. In this survey of present-day tobacco farmers, 81 per cent of all refugees working for wages in Malawi worked in tobacco estates and 73 per cent of the tobacco labourers worked in Kasungu.
} 
headed with them to Kasungu, where they stayed for eight years. There he worked pa mwezi (on a monthly basis) on a large farm with over 350 workers. He estimated that half of the workers were Mozambicans. Isaac, a young single man during the war, worked in Kasungu as a ticketi (seasonal worker). Like most ticketi in Kasungu, he was employed from August to May and would return every year to stay with his parents in the refugee settlements on the border. Like many other respondents, Samuele, who went to Kasungu as a tenant, found the work on tobacco farms harsh but unavoidable in the absence of better alternatives. Tenants received land from the owners of the farm, but were not allowed to own cattle or grow their own maize. All the food had to be bought from the farm and was discounted at arbitrary prices at the end of the tenancy. For large families, the income from tenancy arrangements was often insufficient. Against the wishes of the landlords, households would be forced to engage in petty trade or hire themselves out in order to make ends meet.

Refugees from Angónia felt the accelerated commodification of livelihoods acutely during their time in Malawi. Their landlessness made them ever more dependent on market engagements and wage employment for subsistence. These wartime labour relations in many ways mirrored longer historical dynamics of labour migration. The Malawian tobacco estates actively employed refugees with no land of their own and few livelihood alternatives, just as the sugar estates of the lower Zambezi and the South African mines had previously incorporated the cheap labour of migrants. The coexistence in Malawi of forced displacement and wage employment was not a coincidence: displacement defined the terms in which refugees became integrated into the labour force as well as their position and function in the reproduction of agricultural capital in Malawi. The labour stories of Mozambican refugees show that their employers' search for migrant labour was not reactive, but rather an active attempt to mobilize workers whose structural position in production was undermined by their separation - as a consequence of the war - from the land.

Most Mozambican refugees returned from Malawi in the years immediately following the end of the war in 1992, largely motivated by the prospect of regaining access to land. The news of family members doing well after adopting tobacco convinced many others who had remained in Malawi as farm workers to return to Mozambique. Lineage elders led the process of identifying boundaries and re-allocating land. Heads of lineage and family elders were also in charge of accommodating late returnees, while the nyakwawas - the customary villagelevel chiefs - adjudicated disputes outside kin groups. During the years spent in Malawi, families had grown and subdivided and consequently their need for land had changed. The process of organizing the return and re-adjudicating land was not free of conflict, but all those interviewed did succeed in gaining access to fields: most people agree that landlessness is extremely rare in Angónia. What demanded more effort and investment, and what more clearly contributed to an early differentiation of households, was clearing the fields for cultivation. To pay for the help necessary to prepare the fields, people relied on income from ganyu (casual work) and remittances from household members still working in Malawi. Those with savings or access to remittances cleared the fields more rapidly, restarted agricultural production and were in a better position to take up tobacco a few years later. Labour-scarce households found it harder to start farming and were more dependent on casual work and humanitarian assistance. 


\section{The complex network of labour relations in contract farming}

The return of the Mozambican refugees in the mid-1990s coincided with a fall in the volume and value of tobacco exports from Malawi linked with the liberalization of tobacco agriculture. Similarly, the short-term effects of the fast-track land reform and the macro-economic crisis in Zimbabwe explain the considerable reduction in tobacco exports from that country during the same period (FAOSTAT 2014). Multinational tobacco traders operating in these countries were well aware that refugees with wartime experience producing tobacco were returning to Mozambique. Furthermore, during the period of post-conflict reconstruction the Mozambican state focused its development strategy on attracting foreign investment by offering tax breaks and minimal regulation. Under these conditions, tobacco-trading companies expanded their sourcing of tobacco to Mozambique and successfully compensated for the uncertainties of tobacco farming in Malawi and Zimbabwe.

Initially, tobacco was introduced in every province of central Mozambique where the agro-ecological conditions were favourable. The total output has since reached 73,000 tonnes per year and the number of growers expanded rapidly, reaching 130,000 tobacco farmers in present-day Mozambique. Tobacco now accounts for roughly 40 per cent of the value of all agricultural exports. Mozambique produces 2 per cent of the tobacco traded globally and is one of the main sources of burley tobacco in the world (FAOSTAT 2014). However, this rapid expansion was not uniform; tobacco production is now concentrated in the provinces bordering Malawi and particularly in Angónia, Mozambique's largest tobacco-producing district. It is estimated that Angónia accounted for 22.4 per cent of the area cultivated in tobacco and 33.5 per cent of the total output in 2011. Roughly one in every three households in the district produces tobacco under contract and the crop has triggered agricultural intensification and an overall increase in output and revenue (INE 2011; DPA 2011; Pérez Niño 2014). The tobacco boom could therefore be described as a success story for these borderland districts. However, a closer look at the functioning of the contract farming scheme reveals a more complex story.

The lack of alternatives was one important factor. Tobacco was also introduced in Manica, the Mozambican province bordering Zimbabwe. But, unlike in those provinces that border Malawi - Tete and Niassa - tobacco did not prosper there. The districts in Manica where tobacco was grown are closely integrated with the large Mozambican urban markets of Chimoio and Beira and have access to better services and infrastructure. Many different cash crops are grown in this area, and the proximity of agro-industrial complexes and urban centres creates a more dynamic labour market. In contrast, the districts bordering Malawi were too far from large markets to make long-distance trading in perishable goods viable in the post-war decade. ${ }^{11}$ Furthermore, the large population size of these districts and the availability of Malawian migrant workers were compatible with a more labour-absorbing activity, such as tobacco. Whereas tobacco was just one among an array of different livelihood options open to farmers in Manica,

\footnotetext{
${ }^{11}$ With better roads and logistics, there is now a dynamic market for tomatoes and other vegetables from Angónia that reach larger towns and cities in central Mozambique.
} 
in Tete tobacco is among the few viable high-value crops available, even if it requires a massive labour effort from households and low-paid hired-in labour. While contract farming is an effective avenue for accumulation from below for some producers in a comparatively isolated borderland such as Angónia, such accumulation is made possible only by context-specific labour conditions. What enables it is the capacity to mobilize cheap labour power and the relatively fewer employment and income-generating opportunities on offer.

Tobacco contracts appeal to small-scale farmers in Angónia because tobacco revenue per hectare tends to be higher than revenue for other cash crops, the market for the product is guaranteed by the contract, and the transport costs are paid by the company. However, unlike non-contracted crops, there is no room for price negotiation since the company sets prices unilaterally at the beginning of the commercial season and producers are contractually prevented from selling to any other party. The contract farming scheme finances production via credits for inputs. The threat of losing the contract and peer pressure within producer clubs set up by the tobacco buyers are disciplining mechanisms that push households into performing on time the tasks necessary to produce the contracted quantity of tobacco, and to meet given quality standards, in order to clear their debts. Non-mechanized, rain-fed tobacco agriculture is extremely labour intensive. Although households have some control over the quantity and intensity of the work effort, they have no way of influencing the classification and the pricing of tobacco, which are major sources of tension in relations between farmers and the company. Similarly, production losses due to poor health, climatic shocks or generalized force majeure (chance occurrence and unavoidable accident) have no way of being transmitted to tobacco prices because of the contracts' pricing mechanism. This, in addition to the absence of agricultural insurance, means that losses in production are shouldered exclusively by producers, and that buyers are insulated from their effect via the suppression of the market mechanism.

The circumstances of farming have changed from the labour migration period. Then, cash crop farming took place in irrigated gardens (madimba). The postconflict adoption of tobacco resulted in a relocation of commercial crop production to the minda, the larger rain-fed fields. Minda demand more work for preparation and tilling, while freeing the comparatively smaller madimba for horticulture. Similarly, the practice of using work parties, arguably so necessary when households faced labour shortages during the colonial period, has given way to a situation in which husbands and wives work together on their farms, and in which there is a more intense hiring of casual workers (ganyu). New forms of labour mobilization have emerged around tobacco production, involving seasonal migrants and labour tenants. In contrast to the neighbouring Malawian districts that did not take up tobacco, ganyu workers are regularly paid in cash and relatives of the wife or the husband are very rarely hired for this kind of labour. Respondents explain that relatives are not available, since they are farming tobacco themselves. But narratives also signal that hiring relatives to do ganyu, formerly an idiom of support and solicitude to them, as Englund observed in neighbouring Dedza in the 1990s (1999), now tends to be avoided.

Since households in the district generally have access to agricultural land, the main constraint on taking up tobacco contracts is the capacity to mobilize labour. Analysis stemming from the survey conducted in Angónia identified two 
groups of tobacco-producing households. The first group is composed of households that are not in a position to hire labour other than casual workers on an occasional basis. In this group, most of the work is done by members of the household. ${ }^{12}$ These households constitute the bulk of the farmers and the area they devote to growing tobacco rarely exceeds one hectare. In the second group are households that hire labour regularly. They are less numerous but account for a large share of the total output, and their capacity to mobilize labour determines the area they plant with tobacco.

In the first group of households, in which most labour is supplied by family members, significant contradictions emerge. Sources of intra-household tension include decisions regarding the labour time allocated to tobacco and other cash and food crops; the negotiation of gender roles in productive and reproductive activities in relation to the intense demands of tobacco; and the use of the revenue from tobacco. The labour contribution of young unmarried men working in the family fields has become critical in this uxorilocal region, where young men used to migrate for work before their first marriage. According to the interviews conducted with tobacco farmers, it is now harder for young men to migrate and most stay and work with their parents in exchange for some contribution to a wedding fund. ${ }^{13}$ The end of labour out-migration has thus translated into a greater dependence of unmarried men on their parents to accumulate this fund. (Parents are, of course, equally dependent on the labour contribution of young men.) Moreover, the tobacco contracts, with few exceptions, are signed by husbands, who were similarly in charge of cash cropping and income generation in the past. On the other hand, the land used for cultivation most frequently is that of the wife. This is the case because, in this setting where most married couples live uxorilocally, these are the fields closer to the homestead; their proximity makes it easier to tend to the very valuable tobacco during the months when it dries in the barns. This scenario of men in charge of tobacco contracts and production on women's land can lead to conflicts between the household and other relatives with claims over the same land, and is frequently mentioned as problematic in cases where the couple separates.

Labour relations are significantly different in those households where most of the labour inputs come from hired-in workers. These households use a combination of casual workers engaged for task-based work (ganyu) and seasonal migrant workers (seasoni) who come from Malawi and live with their employers during the growing and curing season from late September to July. Ganyu workers are villagers and neighbours, both men and women, who rely on a combination of farming, petty trading and occasional wage work. Since people doing ganyu do not grow tobacco themselves, they tend to be available for short spells of work during peak labour periods. However, the flexibility of ganyu can work against tobacco farmers when labour demand is at its peak and available ganyu workers are harder to find. In order to secure a more reliable workforce, larger farmers recruit migrant seasonal workers. These, for the most part, are young

\footnotetext{
${ }^{12}$ The use of child labour is the most serious cause for cancellation of the contract. Farmers take this seriously and there was no evidence of child labour being incorporated into production.

${ }^{13}$ Although there is no lobola in this part of Mozambique, young men in Angónia are expected to contribute to the expenses of setting up a household with their new wives.
} 
Malawian men looking for wages paid in Mozambican meticais, which are competitive once converted to Malawian makwacha. The various time-sensitive tasks in tobacco growing and curing require a reliable workforce and any delays cause a deterioration in the quality of the leaf, which easily translates into losses in the phase when leaves are classified. Therefore, the disciplining of hired-in labour becomes critical. This is not so much the disciplining of the day-to-day work the workers live and work alongside household members - as it is a question of making sure that labour is available during peak work periods. Tobacco farmers delay all payments until the end of the marketing period as a way to ensure that migrant workers do not change employers midway through the contract. This reproduces the asymmetry that exists between the farmers and the tobaccotrading company: the hired-in workers stand to lose the totality of the wages due to them if they do not stay on the farm for the whole season, and this precarious bargaining position compromises their ability to resist potential abuses or poor labour conditions. The negotiation of labour conditions is central because labour costs are the highest fixed costs of tobacco producers (Benfica et al. 2005; Pérez Niño 2014). The fragmented and unregulated nature of the sector, and the number of small farms hiring a few workers each, also makes attempts at labour organization and collective action extremely difficult for seasonal migrants from Malawi.

Finally, farmers with access to large tracts of land and contracts for tobacco can engage Malawian migrant families as labour tenants. The tenants receive all inputs from the landlords, including food for the whole season. They are given one or two hectares of land, which they farm with their families - even sometimes hiring casual labourers. At the end of the season the tobacco bales that tenants produce are bought by the landlords at a flat rate that includes a deduction for the inputs advanced. The landlords retain any quality premium from the sale of tobacco to the company. The use of tenants allows land-rich households to expand their tobacco production beyond the area that they can farm themselves. Sharecropping arrangements help large farmers accumulate in agriculture, since part of their profits here comes from the production of maize and the sourcing of other productive inputs, which they advance on credit to the tenants, as well as from the margins farmers obtain from the sale of their own tobacco and that produced by tenants. In sum, labour hiring and sharecropping are different ways in which some tobacco-farming households can overcome the scale limits imposed by the high labour demand of tobacco farming.

However, not all households have access to hired-in labour and tenants, since both presuppose a level of liquidity and food production that surpasses the reproductive needs of the household. Access to large plots of land, animal traction, accumulated savings or local credit are necessary for expanded hiring but are not available to all. Different individual and household socio-economic trajectories reflect the accumulated effect of a long history of commodified livelihoods.

The tobacco contract farmers hire predominantly Malawian migrants. A host of reasons explain this historical reversal in the post-war period. First, it can be argued that the local labour supply is more limited since contract farming transformed the labour migrants who formerly left the district into present-day resident commodity producers. So many households are engaged in tobacco farming in Angónia that it is now arguably more difficult to find workers at peak labour times. Further, even those who do not grow tobacco have access to land, which 
gives them a base for growing other crops or engaging in other livelihood strategies. Second, the land tenure structure is very different on either side of the border. In Malawi, the historical development of estates and demographic pressure have created groups of rural dwellers without access to enough land for farming, while this is not yet the case in Angónia. Third, those who employ migrant workers benefit from an array of spatial effects: the separation of the workers from their areas of origin and delayed payments contribute to these farmers' ability to control labour mobility and to secure a regular supply of labour. Finally, the higher purchasing power of the metical makes the wages more attractive to these migrants, who return to Malawi and use them there.

As this description of productive arrangements and labour relations shows, contract farmers are highly diverse, not only in terms of the scale of their operation and the organization of production but also in terms of the conditions they face, the sources of compulsion and their production strategies. Similarly, the risks that, according to institutionalist approaches, are diffused by the contract arrangement are, in the case of Mozambican farmers, shifted to producers. Importantly, risks and costs can be handed down further to workers and tenant farmers in some cases, while in other cases they are assimilated by the household.

There are consequently several sources of power asymmetry in this type of contract farming: between tobacco farmers in general and tobacco buyers; between landlords and tenants; between employers and migrant workers; and within households. Farmers attempt to bend the rules of a system in which prices are imposed and over whose classification process they have no control, by using tactics such as introducing foreign objects into the sewn tobacco bundles that make up the bales in order to augment the weight of tobacco. Disgruntled workers do leave the farms on which they work, often taking with them a bicycle or other valuable assets to compensate for the wages that will not be paid in such cases. Labour tenants receive little compensation for the tobacco they produce, but tenants and landlords develop clientelistic relations that in time can pay off. Sharecropping works in some cases as a stepping stone to farming for migrants. Those who manage to save or borrow some money from their landlords can eventually negotiate access to land and obtain their own farming contracts. Examples such as these illustrate that, within the skewed power relations that characterize contract farming in Mozambique, farmers, workers and households act in ways that create alternatives and give them some control.

Labour migration has shaped the livelihoods of people in Angónia since the late nineteenth century. By the end of the Mozambican civil war, when it became clear that labour migration could no longer be relied upon as the main source of cash income, its decline led to a reorganization of the use of land and labour within households. Subsistence-oriented farming was not viable for households that by then had depended for decades on markets for selling agricultural surpluses, buying food, hiring casual workers and acquiring the tools and consumer goods that sustained their form of living. The adoption of tobacco in contract farming arrangements in the post-conflict period reveals the particularities of the transition to post-migratory livelihoods in terms of land and labour use. The most striking changes include the shift towards rain-fed fields as the main location of commodity production and the monetization of hiring casual labour, which now only rarely involves relatives. As a consequence, agricultural intensification has taken place 
alongside the amplification of socio-economic differentiation. This is signalled by the emergence of groups of people who mostly sell their labour but are no longer related to the households that employ them.

\section{Conclusion: migrants into contract farmers}

By unpacking labour relations in the accounts of contract farmers, a social configuration is revealed that is more complex and multi-layered than the simple opposition between firms and farmers. The tobacco produced and purchased in the scheme embodies social labour time stemming from unpaid household labour, hired-in migrant workers and sharecroppers. In order to advance discussions about contract farming, this article has studied these labour relations, thus filling a gap in the literature on contract farming in general and in Mozambique in particular.

The Angónia case study shows solid evidence of linkages between labour migration and contract farming. Individual life trajectories and household stories confirm that many of the former labour migrants - by virtue of the historical process detailed above - became mainly petty commodity producers, and that the character of the district changed accordingly. In a densely populated borderland such as Angónia, both labour out-migration and contract farming in the production of a labour-intensive commodity are forms of mobilizing the abundant labour available in the district. Each form of organizing production reflects the social, political and historical context in which it takes place. As commodification progressed, market compulsion replaced taxation and forced labour as the motivation for engaging in migrant labour and later in contract farming. In the case of labour out-migration, the migrant labour system compensated for the limited capacity of capitalist investment to reach Angónia and was based instead on the attempt, grounded in the political economy of the colonial regime, to force the male population into becoming a mobile workforce. In contrast, the contract farming scheme allows the population of Angónia to participate in situ in the production of commodities for export. The end of the migrant labour system in Angónia was mediated by its particular political economy and shaped the development of its agrarian structure thereafter. The long history of commodity relations, the implications of its location on an international borderland and the land tenure structure are all unique to Angónia. In the colonial period, workers were transported away from the district while the reverse was the case in contract farming, but in both cases border effects allowed the mobilization of cheap labour and in both periods migrant workers have contributed substantially to production. The development of the tobacco sector is a good example of the way in which the coordinated provision of credit, inputs and logistics allows family-based smallscale farmers to produce a traded commodity meeting stringent quality standards. But this comes at the expense of unpaid household labour and the exploitation of cheap informal migrant workers.

The contract farming arrangement supresses both the negative and the positive aspects of trading commodities in the market. It amounts to a continuation - of sorts - of the forced labour regime that similarly halted the emergence of free labour. However, in contrast with migrant labour, in contract farming the uncertainty of production and the responsibility of organizing it fall on the direct 
producers. This is despite the fact that in both labour out-migration and outsourced production in Angónia the wages of employers and prices of buyers failed to cover the costs of social reproduction and households were forced to step in to bridge the gap. Both labour migration and contract farming shaped intra-household relations. In the first case the periodic absence of men determined women's agricultural and reproductive work, while in the contract farming period commodity production required a negotiation of roles within households and the coordination of hired-in workers.

Assessments of contract farming routinely look at the income effect for farmers of participation in these schemes and examine the relations between producers and contracting firms. This case study gives voice to present-day contract farmers and reconstructs their transition into contract production based on their own accounts. Their experiences reveal the complex social relations that underpin contract farming: the advanced socio-economic differentiation that allows some households to hire workers and compels others to work for wages, and the pervasive mobilization of unpaid household work. Acknowledging these dynamics provides for a more nuanced analysis of the effects of contract farming and for understanding how this fits into the longer history of labour mobilization in Southern Africa.

\section{Acknowledgements}

I would like to thank Bill Freund and Stefano Bellucci and the two anonymous reviewers of Africa for valuable comments on an earlier version of this article.

\section{References}

Amin, S. (1972) 'Underdevelopment and dependence in Black Africa: origins and contemporary forms', Journal of Modern African Studies 10 (4): 503-24.

Andersson, J. A. (2006) 'Informal moves, informal markets: international migrants and traders from Mzimba district, Malawi', African Affairs 105 (420): 375-97.

Barrett, C. B., M. E. Bachke, M. F. Bellemare, H. C. Michelson, S. Narayanan and T. F. Walker (2012) 'Smallholder participation in contract farming: comparative evidence from five countries', World Development 40 (4): 715-30.

Baumann, P. (2000) 'Equity and efficiency in contract farming schemes: the experience of agricultural tree crops'. Working Paper 139. London: Overseas Development Institute.

Beinart, W. (2014) 'A century of migrancy from Mpondoland', African Studies 73 (3): $387-409$.

Bellemare, M. F. (2010) 'Agricultural extension and imperfect supervision in contract farming: evidence from Madagascar', Agricultural Economics 41 (6): 507-17.

Benfica, R., J. Zamela, A. Miguel and N. de Sousa (2005) 'The economics of smallholder and households in tobacco and cotton growing areas of the Zambezi Valley of Mozambique'. Research Paper Series. Maputo: Directorate of Economics, Ministry of Agriculture of Mozambique. 
Bijman, J. (2008) 'Contract farming in developing countries: an overview'. Working Paper. Wageningen: Department of Business Administration, Wageningen University.

Bolt, M. (2012) 'Waged entrepreneurs, policed informality: work, the regulation of space and the economy of the Zimbabwean-South African border', Africa 82 (1): 111-30.

Borges-Coelho, J. P. (1991) 'Tete, 1900-1926: O Establecimento de uma Reserva de Mão-de-Obra', Arquivo: Boletim do Arquivo Histórico de Moçambique 10 (October).

Borges-Coelho, J. P. (1993) 'Protected villages and communal villages in the Mozambican province of Tete (1968-1982): a history of state resettlement policies, development and war'. PhD thesis, University of Bradford.

Bush, R. and L. Cliffe (1984) 'Agrarian policy in migrant labour societies: reform or transformation in Zimbabwe?', Review of African Political Economy 11 (29): 77-94.

CEA (1983) Famílias camponesas da Agónia no processo de socialização do campo. Maputo: Centro de Estudos Africanos (CEA), Universidade Eduardo Mondlane.

Christiansen, R. E. and J. G. Kydd (1983) 'The return of Malawian labour from South Africa and Zimbabwe', Journal of Modern African Studies 21 (2): 311-26.

Crush, J. (1995) 'Cheap gold: mine labour in Southern Africa' in R. Cohen (ed.), The Cambridge Survey of World Migration. Cambridge: Cambridge University Press.

Crush, J. and C. Tshitereke (2001) 'Contesting migrancy: the foreign labor debate in post-1994 South Africa', Africa Today 48 (3): 49-70.

Delius, P. (2014) 'Special issue: the making and changing of migrant workers' worlds (1800-2014)', African Studies 73 (3).

DPA (2011) 'Relatorio de produccao de tabaco'. Mimeo. Tete: Direccao Provincial de Agricultura (DPA).

Eaton, C. and A. Shepherd (2001) 'Contract farming: partnerships for growth'. Agricultural Services Bulletin 145. Rome: Food and Agriculture Organization of the United Nations.

Englund, H. (1999) 'The self in self-interest: land, labour and temporalities in Malawi's agrarian change', Africa 69 (1): 139-59.

FAO (2012) Guiding Principles for Responsible Contract Farming Operations. Rome: Food and Agriculture Organization of the United Nations (FAO), Division Office of Knowledge Exchange, Research and Extension.

FAOSTAT (2014) 'Statistical databases'. Rome: Food and Agriculture Organization of the United Nations (FAO).

Farré, A. (2013) 'A broken link: two generations in a rural household in Massinga district, southern Mozambique', Anthropology Southern Africa 36 (3-4): 124-9.

IFAD (2003) Agricultural Marketing Companies as Sources of Smallholder Credit in East and Southern Africa: experiences, insights and potential donor role. Rome: Africa Division II, International Fund for Agricultural Development (IFAD).

INE (2011) Censo Agropecuário 2009-2010: resultados definitivos. Maputo: Instituto Nacional de Estatística (INE).

Ishemu, S. L. (1995) 'Forced labour and migration in Portugal's African colonies' in R. Cohen (ed.), The Cambridge Survey of World Migration. Cambridge: Cambridge University Press. 
Jaffe, S., R. Mkandawire, S. Bertoli and D. Kamkondo (1991) The 'Migrant Smallholders': tenant and laborer participation, remuneration, and social welfare within Malawi's expanding estate sub-sector. Binghamton NY: Institute for Development Anthropology.

Jelsma, I., A. Bolding and M. Slingerland (2010) Smallholder Sugarcane Production Systems in Xinavane, Mozambique: report from the field. Wageningen: Plant Production Systems, Plant Sciences Group, Wageningen University.

Juergensen, O. (1996) 'Peasants on the periphery: a geohistory of rural change in Mozambique, c.1960-1992'. PhD thesis, Queen's University.

Lubkemann, S. C. (2009) 'From circular migrants in the mines to transnational polygynists in the townships: a century of transformation in central Mozambican male migration regimes (1900-1999)', International Migration 47 (3): 51-92.

Mkandawire, T. (1985) The Informal Sector in the Labour Reserve Economies of Southern Africa with Special Reference to Zimbabwe. Harare: Zimbabwe Institute of Development Studies.

NEPAD (2006) 'Contract farming offers fresh hope for Africa's declining agriculture'. East Africa Policy Brief 2. Midrand, South Africa: Sida, World Agroforestry Centre and NEPAD Secretariat Agriculture Unit.

Newitt, M. (1995) A History of Mozambique. London: Hurst.

Newitt, M. and C. Tornimbeni (2008) 'Transnational networks and internal divisions in Central Mozambique', Cahiers d'Études Africaines 192 (4): 707-40.

Ochieng, C. M. O. (2010) 'The political economy of contract farming in tea in Kenya: the Kenya Tea Development Agency (KTDA), 1964-2002' in B. Harriss-White and J. Heyer (eds), The Comparative Political Economy of Development: Africa and South Asia. London: Routledge.

O'Laughlin, B. (2000) 'Class and the customary: the ambiguous legacy of the indigenato in Mozambique', African Affairs 99 (394): 5-42.

O'Laughlin, B. (2002) 'Proletarianisation, agency and changing rural livelihoods: forced labour and resistance in colonial Mozambique', Journal of Southern African Studies 28 (3): 511-30.

O'Laughlin, B. (2013) 'Land, labour and the production of affliction in rural Southern Africa', Journal of Agrarian Change 13 (1): 175-96.

O'Laughlin, B. and Y. Ibraimo (2013) A Expansão da Produção de Açúcar e o Bem-Estar Dos Trabalhadores Agrícolas e Comunidades Rurais em Xinavane e Magude. Cadernos IESE 12. Maputo: Instituto de Estudos Sociais e Económicos (IESE).

Oya, C. (2012) 'Contract farming in sub-Saharan Africa: a survey of approaches, debates and issues', Journal of Agrarian Change 12 (1): 1-33.

Pérez Niño, H. (2014) 'Post-conflict agrarian change in Angónia: land, labour and the organisation of production in the Mozambique-Malawi borderland'. $\mathrm{PhD}$ thesis, SOAS, University of London.

Porter, G. and K. Phillips-Howard (1997) 'Comparing contracts: an evaluation of contract farming schemes in Africa', World Development 25 (2): 227-38.

Potts, D. H. (2010) Circular Migration in Zimbabwe and Contemporary SubSaharan Africa. Woodbridge: Boydell \& Brewer.

Prowse, M. (2012) Contract Farming in Developing Countries: a review. Series A Savoir. Paris: Agence Française de Développement. 
Prowse, M. (2013) 'A history of tobacco production and marketing in Malawi, 1890-2010', Journal of Eastern African Studies 7 (4): 691-712.

Sautier, D., H. Vermeulen, M. Fok and E. Bienabe (2006) Case Studies of AgriProcessing and Contract Agriculture in Africa. Santiago de Chile: RIMISP.

Smart, T. and J. Hanlon (2014) Galinhas e cerveja: uma receita para o crescimento. Maputo: CIEDIMA.

Tornimbeni, C. (2000) 'Lavoro migratorio in Africa centro-meridionale e il distretto di Tete, Mozambico, 1890-1945', Africa: Rivista trimestrale di studi e documentazione dell'Istituto italiano per l'Africa e l'Oriente 55 (3): 309-37.

UNCTAD (2009) World Investment Report 2009: transnational corporations, agricultural production and development. Geneva: United Nations Conference on Trade and Development (UNCTAD).

Vail, L. and L. White (1980) Capitalism and Colonialism in Mozambique: a study of Quelimane district. London: Heinemann.

Watts, M. J. (1994) 'Life under contract: contract farming, agrarian restructuring, and flexible accumulation' in P. D. Little and M. J. Watts (eds), Living under Contract: contract farming and agrarian transformation in sub-Saharan Africa. Madison WI: University of Wisconsin Press.

Will, M. (2013) Contract Farming Handbook: a practical guide for linking smallscale producers and buyers through business model innovation. Bonn: Deutsche Gesellschaft für Internationale Zusammenarbeit.

Woodhouse, P. (2012) 'Agricultura, Pobreza e a Receita do PARP' in Desafios para Moçambique 2013. Maputo: Instituto de Estudos Sociais e Económicos (IESE).

World Bank (2005) Mozambique: contract farming and supply chain financing. Report 33406. Washington DC: World Bank.

World Bank (2007) World Development Report 2008: agriculture for development. Washington DC: World Bank.

\begin{abstract}
As contract farming gains ground as a form of agricultural production in Southern Africa, there is growing interest in its effects on patterns of investment and production as well as in its potential to provide small farmers with access to export markets. However, the relation between contract farming and the region's long history of labour migration has largely escaped analysts and scholars working on Southern Africa. This article traces the changing livelihoods of those who experienced the demise of the migrant labour system and displacement during the civil war, and who now engage in contract farming in Angónia, a densely populated district in Tete Province, central Mozambique. In the decades since the end of the war, contract farming thrived among former migrants with access to land and few alternative sources of income and employment. If historical labour migration from Angónia involved attempts by employers to externalize the responsibility for social reproduction onto households, contract farming amounts to the internalization by households of the opportunities, risks and tensions involved in the production of high-value export commodities. By analysing farmers' accounts of producing under contract and linking this to their households' longer histories of labour mobilization, this article sheds light on people's experiences of working for wages, working on their own account and hiring workers, as households became the new sites of commodity production.
\end{abstract}




\section{Résumé}

Alors que l'agriculture contractuelle gagne du terrain en tant que forme de production agricole dans le sud de l'Afrique, on s'intéresse de plus en plus à ses effets sur les schémas d'investissement et de production, ainsi qu'à sa capacité à permettre aux petits exploitants d'accéder aux marchés d'exportation. Or, le lien entre l'agriculture contractuelle et la longue histoire de la migration de la main-d'œuvre dans la région a largement échappé aux analystes et aux chercheurs qui s'intéressent au sud de l'Afrique. Cet article retrace l'évolution des moyens de subsistance de ceux qui ont connu l'effondrement du système de travail migrant et le déplacement de la population durant la guerre civile, et qui aujourd'hui pratiquent l'agriculture contractuelle dans le district densément peuplé d'Angónia, dans la Province de Tete, au cœur du Mozambique. Au cours des décennies qui ont suivi la fin de la guerre, l'agriculture contractuelle a prospéré parmi les anciens migrants ayant accès aux terres et peu d'autres sources de revenu et d'emploi. Si la migration historique de la main-d'œuvre d'Angónia faisait intervenir des tentatives par les employeurs d'externaliser la responsabilité de la reproduction sociale sur les ménages, l'agriculture contractuelle revient quant à elle à une internalisation, par les ménages, des opportunités, des risques et des tensions associés à la production de produits d'exportation à valeur élevée. En analysant ce que rapportent les agriculteurs de leur expérience de production sous contrat, et en rapprochant cette analyse de la longue histoire de la mobilisation de la maind'œuvre qu'ont connue leurs foyers, cet article apporte un éclairage sur l'expérience qu'ont ces personnes du travail salarial, du travail indépendant et de l'emploi de travailleurs, à une période où les foyers sont devenus les nouveaux sites de production. 